\title{
INTROVERT LEARNERS' NEED ANALYSIS OF ENGLISH-SPEAKING ACTIVITY
}

\author{
Dinda Amalia, Nida Husna \\ Syarif Hidayatullah State Islamic University of Jakarta, Indonesia \\ (dindaamalia401@gmail.com)
}

Received: $18^{\text {th }}$ July 2019; Revised: $23^{\text {th }}$ October 2019; Accepted: $28^{\text {th }}$ December 2019

\begin{abstract}
The objective of this research was to reveal the introvert learner's necessities, lacks, wants and learning needs in English speaking activity. This research was conducted at three state Islamic junior high schools in South Jakarta in order to solve the introvert learners' problems deals with self-confidence and social interaction in English speaking activity. It was presented in a mixed-method research and used the explanatory sequential strategy. The participants in this research were 106 introvert learners on the eighth grade for quantitative data meanwhile nine introvert learners and four English teachers for qualitative data. The data of the study were collected through questionnaire and interview. The quantitative data were analysed using simple descriptive statistic while the qualitative data were analysed using Creswell's theory. The study showed that introvert learners learn English speaking skill in order to communicate properly in English and facilitate their learning in other skills. Since the difficult learning material and the lack of vocabulary were the main obstacles for introvert learners, the English teacher can give them keywords and examples, then teach based on their interest in speaking activity to support the learning process. In this regard, the introvert learners like to discuss dialogues and experience topics by pairs, watching English movies, and listening to English songs. By identifying the necessities, lacks, wants, and learning needs, the teacher can facilitate the learning process through a friendly atmosphere.
\end{abstract}

Key Words: need analysis; introvert learners; english speaking activity

\section{ABSTRAK}

Penelitian ini bertujuan untuk mengungkapkan tujuan, kekurangan, minat, dan kebutuhan belajar siswa introvert dalam aktivitas berbahasa Inggris. Penelitian ini dilasanakan di tiga MTs Negeri di Jakarta Selatan dengan tujuan untuk menyelesaikan masalah siswa introvert terkait kepercayaan diri dan interaksi sosial dalam kegiatan berbahasa Inggris. Penelitian ini disajikan dalam penelitian metode campuran dan menggunakan strategi sekuensial penjelasan. Peserta dari penelitian ini adalah 106 siswa introvert di kelas delapan untuk data kuantitatif dan sembilan perwakilan siswa introvert dan empat guru bahasa Inggris untuk data kualitatif. Data penelitian dikumpulkan melalui angket dan wawancara. Data kuantitatif dianalisis menggunakan statistik deskriptif sederhana sedangkan data kualitatif dianalisis menggunakan teori Creswell. Studi ini mengungkapkan bahwa siswa introvert mempelajari keterampilan berbahasa Inggris untuk berkomunikasi dengan baik dalam bahasa Inggris dan memfasilitasi pembelajaran mereka di kemampuan lainnya. Karena materi pembelajaran yang sulit dan kurangnya kosa kata adalah hambatan utama bagi siswa introvert, guru bahasa Inggris dapat memberi mereka kata kunci dan contoh, kemudian mengajar berdasarkan minat mereka dalam kegiatan berbicara untuk mendukung proses pembelajaran. Dalam hal ini, siswa introvert suka mendiskusikan dialog dan topik pengalaman secara berpasangan, menonton film berbahasa Inggris, dan mendengarkan lagu-lagu bahasa Inggris. Dengan mengidentifikasi kebutuhan, kekurangan, minat, dan kebutuhan belajar, guru dapat memfasilitasi proses pembelajaran melalui suasana yang bersahabat.

Kata Kunci: analisis kebutuhan; siswa introvert; aktivitas berbahasa inggris

How to Cite: Amalia, D., Husna, N. (2019). Introvert Learners' Need Analysis of English-Speaking Activity. IJEE (Indonesian Journal of English Education), 6(2), 91-108. doi:10.15408/ijee.v6i2.15466 


\section{INTRODUCTION}

Speaking is someone's ability to express himself/herself orally in a given meaningful context. It is one of the four language skills that play a crucial role in communication. Generally, speaking skill requires several components. It is more than knowing its vocabulary and grammar. Someone has to comprehend the language itself afterwards learn how to use the language fluently and appropriately. As a result,

Al Hosni (2014) considered speaking as an essential skill because the success of language learning is based on the learner's capacity to engage in oral activities. It is in line with Bergil (2016) who clarified the aim of language learning is able to use target language communicatively in accordance with an education, occupation, travelling and the other field. This indicates learners who learn a language are expected to be able to speak the target language.

However, in order to be able to speak the target languages properly including English, there are many individual differences that influence the learners' success in language learning such as language aptitude and motivation (Dörnyei, 2005). Besides those factors, He also pointed out that personality affects the learners' success in language learning. This could happen because personality influences someone's behaviour in communication. The learners who have different personality probably attach different verbal and interactive behaviours, which will give an effect on their speaking performance in classroom activities or daily activities (Abali, 2006). For instance, verbal behaviour can refer to someone's behaviour in talking whether he/she fills much pause and repetitive words in his/her talk or can speak fluently without having hesitation. Meanwhile, interactive behaviour can refer to someone's behaviour in responding to people's utterance, whether he/she can respond directly or ask for repetition and clarification. Therefore, different personality represents different behaviours as well.

Generally, personality is categorized into extrovert and introvert. According to Altunel (2015), individuals who inclined toward extrovert personality, give and get energy from outside sources by connecting with other individuals and environment. As a result, extrovert people are sociable and expressive. On the other hand, individuals who lean toward introvert personality are progressively concerned with the inward universe of thoughts and experiences. Introvert people get their 
energy through reflection and shelter be private. In other words, both of this personality is contradictory.

Relating these two personalities to English speaking activity, extrovert and introvert learners have a different response. The extrovert learners involve themselves actively in classroom speaking activities. It is in line with Omar (2015), who believed that the extrovert learners have more opportunities to interact with other learners. This could happen because extrovert learners are sociable people. They likely involve in oral activities and improve language-use opportunities. However, introvert learners tend to have problems in terms of selfconfidence and social interaction. As Elfiza (2017) expressed that introvert learners are progressively keen on their own considerations or emotions than in things outside themselves. They are frequently timid and reluctant to talk in front of the class. Similarly, Hakim (2017) showed that learners who have an introvert personality feel embarrassed and talk less during classroom activities.

In line with those researchers, the researcher's investigation in preliminary observation revealed that the introvert learners feel anxiety and unconfident to share their ideas among their friends. They prefer to be a listener and quite persons in English speaking activity. As a result, English teachers face difficulty in teaching speaking to introvert learners. Furthermore, they have lower achievement in English speaking performance in the class. This statement is proven by Dörnyei (2005), who reported that the introvert learners' speech was slow down, they tend to make errors regularly, and they are unfit to deliver the speech with incredible length. Based on those reasons, the researcher is interested in investigating the introvert learners in the present study.

As the issue of introvert learners has received considerable critical attention, there have been some studies concerning introvert learners. To begin with, Hakim (2015) examined EFL teachers' challenges in teaching speaking for introvert learners. The main problems faced by the teachers were the learners' less motivation in speaking class and the irrelevant teaching instruction (material and syllabus). Davidson \& Pelletier (2015) informed that introvert learners have higher stress levels than the extrovert learners, and they also have lower evaluations concerning with the interpersonal behaviour. Hiouani (2016) then reported that introvert learners face difficulty when performing tasks orally. They require more time to understand the information and 
construct any ideas before sharing them to their friends or teacher in the class. Similarly, Wen (2017) argued that introvert learners have an obstacle to adapt and involve themselves in classroom English speaking activities. Thus, these studies show that introvert learners need to be examined in order to solve their problems in speaking activities.

Due to the facts that the introvert learners face difficulties in the speaking activities, teachers and educators are demanded to analyze their learners' need in the learning process. Need analysis is an indispensable key in language learning. Need analysis can be characterized as a fundamental part of gathering detailed information that will serve as a premise in educational plan improvement as well as in determination and assessment of instructing exercises (Poedjiastutie \& Oliver, 2017). It implies that need analysis enables the teachers to decide whether the current learning addresses the needs of learners or to perceive a gap between what students can do and what they should certainly do. Also, it involves doing some kinds of activity with learners in order to discover the needs of a particular group, because a good understanding of learners can contribute to successful learning. In this case, the researcher assumed that introvert learners as a particular group of learners. Therefore, need analysis is reasonable for introvert learners because they have a particular need in English speaking activity.

Based on the related studies, it can be found that need analysis is a vital and necessary element in order to achieve the learning outcomes. It helps the teachers to aware the needs of a particular group and to find out what language points their learners needed to study. Need analysis also helps the teachers to solve the problem related to poor outcomes and evaluate whether the learning process run well or not. Relating to the introvert learners as a particular group in the present study, there has been no previous study of need analysis which dealt with the introvert learners. Therefore, the researcher attempts to present a different account of need analysis related to the introvert learners and English speaking activity.

In view of all that has been mentioned so far, the main objective of this study is to reveal the introvert learner's necessities, lacks, wants and learning needs in English speaking activity based on the methodology of need analysis. Accordingly, the researcher applied mixed-method research which qualitative and quantitative data are required in conducting the present study. To obtain 
a deep study of introvert learners in English speaking activities, this study then was conducted at three state Islamic junior high schools at South Jakarta. Moreover, the second-year learners which categorize as teenagers are considered to be the appropriate level to be examined. Thus, the result of this study, hopefully, will be valuable for teachers in teaching speaking for introvert learners.

\section{METHOD}

The present research was conducted at MTs Negeri 03 Jakarta, MTs Negeri 13 Jakarta, and MTs Negeri19 Jakarta. In this mixed-method research, the participants were 106 introvert learners on the eighth grade for quantitative data meanwhile nine introvert learners and four English teachers for qualitative data. The researcher used the mixed method because the researcher collected two different data which they were quantitative and qualitative data in order to gain very comprehensive and sufficient information related to the needs of introvert learners. Additionally, the explanatory sequential strategy has been used in presenting the answers to the research questions. This strategy was initialled by collecting the quantitative data firstly and then collecting the qualitative data to support and explain the quantitative results.

There were three instruments which have been used by the researcher. First of all, the researcher classified the learners into extrovert and introvert learners using Eysenck's Personality Questionnaire (EPQ) adopted from Francis et al. (2006). The participants were administered the Indonesian version of the EPQ test, and they answered the test by marking either "Yes" or "No" for each question. Moreover, the learners who were signified as the introvert learners became the following participants in the research. Second, the researcher used a questionnaire (quantitative data) to obtain information related to introvert learners' need analysis. The Indonesian questionnaires which consist of 20 multiple choices were administered to introvert learners at three state Islamic junior high schools. Third, the researcher used the interview (qualitative data) to obtain information related to the introvert learners' needs based on the perspective of English teachers and the representative of introvert learners who have the highest score in personality test in each school. The total numbers of questions in the interview are 13 questions for English teachers and 11 questions for the representative of introvert learners in each school. 
In analysing the data, the quantitative data were analysed using simple descriptive statistic (frequency and percentage) and the qualitative data were analysed using Creswell's Theory. The researcher used content validity to the need analysis questionnaire. As a result, the researcher has compiled the blueprint of need analysis questionnaire from several sources and used the assessment of expert judges adopted form Ihsan (2015). Likewise, the researcher used methodology triangulation and theory triangulation in order to get a validity and credibility for qualitative data.

\section{RESULTS AND DISCUSSION}

\section{Results}

The prior participants for a personality inventory test in three schools were 366 learners. Based on the analysis of personality test, it was found that there were 106 introvert learners in this research. The detail information is presented in the table 1 .

Moreover, the result of need analysis at three state Islamic junior high schools in South Jakarta has been organized based on the introvert learners' necessities, lacks, wants, and learning needs in order to answer the research questions.
Table 1. Total of Introvert Learners

\begin{tabular}{lllll}
\hline No & $\begin{array}{l}\text { Schoo } \\
1\end{array}$ & $\begin{array}{l}\text { Total of } \\
\text { Students }\end{array}$ & $\begin{array}{l}\text { Introvert } \\
\text { Learners }\end{array}$ & Percentage \\
\hline 1. & $\begin{array}{l}\text { MTs } \\
\text { 2 }\end{array}$ & 135 & 36 & $27 \%$ \\
2. & MTs & 129 & 41 & $32 \%$ \\
& N 13 & & & \\
3. & MTs & 102 & 29 & $28 \%$ \\
\multicolumn{7}{l}{ Total } & N 19 & 366 & 106 & $29 \%$ \\
\hline
\end{tabular}

First of all, necessities refer to the demands of the target situation. The finding revealed that the introvert learners learn speaking skill in order to communicate properly and facilitate their learning in other skills. Moreover, they considered vocabulary as the most important speaking aspect which the introvert learners need to learn in English speaking activity. Second, the learners' lack concerns with the introvert learners' problems in English speaking activity. The finding showed that the difficult learning material and lack of vocabulary as the main lacks for introvert learners in English speaking activity.

Third, wants refer to the learners' interest in English speaking activity. The finding reported that the introvert learners felt excited and interested when they discuss the interesting topics concerning with own experience, watching English videos with subtitle, and learning dialogue materials in English speaking activity. Fourth, 
learning needs indicates the route how the learners are able to make progress from the starting point (lacks) to the destination (necessities). The finding pointed out that receiving keywords and examples when they experience the difficulties in learning was the teachers' role and input that they need. As a result, listening to the teacher' explanation was the introvert learners' role while learning to speak. The finding also showed that listening English song as their learning style, pairs as the effective work dynamics and translation as the effective learning technique. Hence, the information about the introvert learners' need analysis in three schools was summarized in the table 2 (see Appendix A).

\section{Discussion}

Following the subsections in findings, the researcher concluded some important findings. First, there are two necessities become the main concern in the present study. The first necessity concerns with the introvert learners' goal in learning English speaking skill. Based on the findings, it can be concluded that the introvert learners have two strong reasons why they need to learn English speaking skill. It was proven from the finding which had the same number of percentages in two objectives. The introvert learners' objectives in learning English speaking skill are in order to communicate properly in English and also facilitate their learning in other skills such as listening, writing, and reading.

Accordingly, the first goal is in line with Bergil (2006), who stated that the purpose of language learning is able to use the target language communicatively. The second goal is related to Qutob (2018), who pointed out that speaking is a practice of interactions, which includes sending and delivering information to convey meaningful interactions. It is indicated that there is a collaboration among four language skills in social interaction (Mundhe, 2015). This shows that the learners who learn a language want to be able to speak the language, including the introvert learners.

The second necessity focussed on the speaking aspect which the learners need to learn. Based on the finding, it can be concluded that the prominent aspect which the introvert learners need to learn in the eighth grade was vocabulary. The English teachers in interview session also have some idea about it. Additionally, a previous study which conducted by Swanson et al. (2016) has recognized the importance of vocabulary learning to learners' 
comprehension in middle and high school. Alqahtani (2015) further explained that vocabulary learning is considered as the important part for all language learners including introvert learners because the meanings of new words are very often emphasized and developed whether in books or in classrooms. He also explained that there is a complementary relationship between vocabulary and language use: vocabulary knowledge plays an important role in language use, and language use leads to an increase in vocabulary knowledge. That is to say, all learners including the introvert learners, require vocabulary knowledge to engage in speaking activities.

Second, there are two introvert learners' lacks being discussed in the present research. The first lack deals with the introvert learners' problem in English speaking activity. Based on the findings, the introvert learners' problem in speaking activities was because of the difficult learning material. According to Salam (2017), the learning material can be difficult if it is not based on the needs of learners and teachers. He revealed that good learning materials should be determined by the environment, the development of information technology, and the culture of the community in which education takes place. Related to the present study, this shows that the introvert learners face difficulties to understand and perform the learning materials orally (Hiouani, 2016). One of the introvert learners told in an interview session that the learning material is difficult because they do not understand the meaning of words in the material.

Furthermore, Graves (2000) pointed out several considerations in developing material based on the needs of learners. He stated, "the material should be made relevant to their experience and background, the material must be relevant to their target needs (outside the classrooms), and the material should be relevant to their affective needs" (p.156). As a result, Hakim (2018) attempted to design a speaking module for introvert learners based on cooperative learning to facilitate the introverts to be more active. The module consists of book mapping, explanation about the topics and materials, examples related to the materials, conversation practice, and colourful photographs. According to him, the learning material should contain more activities and represents the competence of cooperative learning to improve the learners' interaction. Therefore, developing supplementary learning material based on cooperative learning for introvert learners is suggested to support the learning process. 
The second lack in the research concerns with the most difficult speaking aspect for introvert learners. The finding revealed that vocabulary is indicated as the most difficult speaking aspect for introvert learners in the eighth grade at three state Islamic junior high schools. This result is also similar to the speaking aspect which they need to learn. This finding is in line with Alqahtani (2015), who realised that the lack of vocabulary knowledge was the largest and the main problem for all second language learners to overcome. According to him, vocabulary can be problematic because many English teachers are not confident about best practice in vocabulary teaching, and they do not know where to begin to form an instructional emphasis on word learning. Cahyono \& Widiati (2015) then presented two major ideas concerning with vocabulary teaching and learning. He remarked in his research that the teachers do not know whether vocabulary teaching should be done directly or vocabulary acquisition should take place through exposure. In addition, the vocabulary can be the most difficult aspect is because there is no rule in vocabulary learning (Alqahtani, 2015). He considered vocabulary as the most sizeable and unmanageable component in language learning. The language learners do not have ideas about what kind of rules apply or which vocabulary items should be learned first by them. As a result, the lack of vocabulary knowledge affects their four language skills, including speaking skill.

However, introvert learners have a more complex problem than extrovert learners related to the lack of vocabulary. Hakim (2017) further clarified the differences between them when they have problems in a speaking activity. According to him, all foreign language learners feel nervous and confused in arranging the words and choosing which words should be spoken. Nonetheless, the problems can sometimes be overcome by the extrovert learners who are easy to have a conversation with other people and highly love to speak even when their speech is wrong (Yulmiastri, Atmowardoyo, \& Salija, 2019). Due to the fact that the extrovert learners are sociable people, they likely involve in oral activities and improve languageuse opportunities (Kristo, 2012). Whereas, for introvert learners, the problems become more intense when fear of making a mistake and lack of self-confidence dominate their feelings. Because introvert learners are uncomfortable in social situations, they tend to be listeners and rarely practice their vocabulary knowledge in the environments such as classroom, 
neighbourhood or home (Wen, 2017). These factors make the introvert learners do not have a range of vocabulary and reluctant to participate in speaking activities. In other words, the introvert learners have fewer opportunities for himself/herself to deal with interaction with other people rather than extrovert learners.

Third, there are five wants to become the main concern in this research. The first want concerns with the favourite English speaking activity and the second want focus on the learners' interest in a speaking activity. Based on the same findings for both of them, it can be concluded that introvert learners like to discuss the interesting topics in a speaking activity. According to $\mathrm{Wu} \& \mathrm{Hou}$ (2015), the discussion can be a favourite English speaking activity because it helps the teachers to activate and engage the learners in the speaking activity. It also helps the learners to get a more in-depth understanding of the topic. They added that discussion generally could be implemented by dividing the learners into pairs or groups.

In line with $\mathrm{Wu} \& \mathrm{Hou}, \mathrm{Li} \& \mathrm{Lam}$ (2013) stated that discussion encourages the members to learn and motivate them to help each other in the learning process. By conducting the discussion activity, the introvert learners are assigned to give a solution, opinion, or responsibility regarding the topic comfortably and delightfully. Similarly, Hakim (2017) in his research highlighted that sharing an idea about an event or finding a solution in a discussion group is an appropriate way to encourage the introvert learners to speak up and interact with other learners. In this way, each group works on each topic for a certain period of time and presents the result in front of the class. As a result, the learners who had been felt shy to speak then began to share their opinion courageously with their friends.

The third want in the present study is learners' interest in pronunciation activity. The findings showed that introvert learners like to watch a video with English subtitle, write the unknown words and recite them in pronunciation activity. Isazadeh, Makui, \& Ansarian (2016) explained that both authentic video materials and instructional videos materials give positive effects for all language learners. In line with the previous researchers, Sari \& Sugandi (2015) pointed out that watching native speakers in a movie or video helps the learners to hear how the words are pronounced. He also added that the learners could know where to put intonation and stress on certain words or sentences after watching. They can 
also differentiate and compare the different accents such as British and American style when the actors are talking in the movies. Pratiwi (2010) also revealed that English movies or videos could affect the learners, including introvert learners, to comprehend the pronunciation. Besides feeling enjoyed, introvert learners can improve their pronunciation skill.

The fourth want refers to interesting topics. Based on the findings, it can be revealed that experience is an interesting topic for the introvert learners in the eighth grade. It is obviously in line with recount text as their learning material in the Eighth grade. Recount text is a text which tells about someone experience or events that occurred in the past (Autila, 2017). It is one of text that helps the learners to develop and tell their experience into written text or spoken dialogue. According to her, the experience can be an interesting topic because the learners can explore and develop their ideas from real life experience or personal record. In line with Autila, Hakim (2017) proposed that real life topics are very suitable for introvert learners. Moreover, Ihsan \& Ardhityawan (2016) proposed diary writing as another method in recount text. The learners can write or share their thoughts, feeling, and response about their experience and something happened in their real life. That is why the introvert learners considered experience as interesting topics in speaking activities.

In addition, the fifth want concerns with the favourite speaking material. The finding revealed that dialogue was the introvert learners' favourite speaking material in the eighth grade rather than a monologue. It is in line with the recent research conducted by Michelene, Seokmi, \& David (2016). According to them, the learners can learn more from dialogue than monologue. The dialogue contains many moves that are absent in monologue. Davies (2019) in his research "the shifting from a monologue to a dialogue" also reported that the dialogic teaching contains several interactions between a teacher and a learner or group of learners in a context of collaboration and mutual support. It allows the learners, including the introvert learners, to have a range of responses before the teacher provides feedback or judgement.

Lastly, there are five introvert learners' learning needs being discussed in the present research. The first learning need refers to the teacher's role in the learning process. The role of the teacher is very important because it will affect the learning success. Hakim (2017) further presented several strategies which the teachers can use to 
teach and improve the introvert learners' speaking skill. The strategies cover improving student discussion, forming role play, creating storytelling, and training interview. These four strategies significantly improve introvert learners' speaking skill. In the end, they dare to speak, although there still make errors in their speech. Based on the finding, it showed that the introvert learners need the teacher who give them keywords when they experience difficulties in the speaking activities. As Zack (2010) stated that the introvert learners usually fill more pause before responding or initiating the interactions. They usually respond to something based on careful consideration and tend to need several times to think before saying something. Moreover, those whom introverts feel embarrassed and talk less during speaking activity. Therefore, giving introvert learners a keyword will help them to participate in a speaking activity.

In addition, the second learning needs also talks about the role, especially the learners' role. Based on the findings, listening to their teacher's explanation was their role while learning the speaking skill. It is in line with Uzer (2018), who pointed out that the introvert learners tend to enjoy listening to others talk about a topic while privately processing the information. This statement is in line with the finding related to the introvert learning style. The introvert learners are indicated as the auditory learners who are good at listening. Kayalar \& Kayalar (2017) pointed out that auditory learners are good at understanding and remembering what they hear as they learn information through auditory representation. Moreover, introvert learners also enjoy lectures, written work, and reading rather than speaking up in the class (Uzer, 2018). Therefore, regarding first learning needs, giving them a keyword will help them to participate and interact with other learners in a speaking activity.

The third learning need is about the work dynamic. Work dynamic or setting refers to the classroom or student arrangements which applied in the learning process (Nunan, 2004). The finding revealed that pairs were the effective work dynamics for introvert learners in a speaking activity. It is line with Nilsson \& Hay (2016) who reported that pairs were the most common group size that the teachers use when working with the group work. Working in pairs provide each of learners a lot of speaking time. They also have more confidence and motivation to complete the task than doing individually. Similarly, Page \& Stoneburgh (2019) considered pair work as the appropriate work dynamic 
for successful conversation in the ESL classroom. Fortunately, the extrovert learners also enjoy to study in pair and group rather than learning alone (Yulmiastri, Atmowardoyo, \& Salija, 2019). Related to the study, pair work is good for the introvert learners in practising the dialogue or conversation, completing worksheets, and discussing the interesting topics.

The fourth learning need focusses on the learning technique. The finding showed that translation was an effective learning technique based on the introvert learners' perspective. According to Jiménez et al. (2015), learners can display the cultural and linguistic understandings during the translation activity in English learning. However, they also added that the communicate purposes are not developed in translation activity. The different idea also comes from teachers in an interview session that role play was the effective learning technique than translation for the introvert learners in a speaking activity. This statement is supported by Alharbi (2015), who said that role play encourages shy learners to participate and discuss their opinion with their partners. Similarly, Hakim (2017) presented the same idea related to roleplay activity for introvert learners. the roleplay activity turns out to be an interesting learning technique because they find the elements of art and entertaining acting. Nevertheless, the researcher considered that these two techniques, whether translation and role-play, are a good activity for the introvert learners to improve their speaking skill.

The fifth learning needs is learning input. Input refers to the spoken, written and visual data that the learners get in the learning process (Nunan, 2004). He added that the data could be provided by a teacher, a textbook, or other sources. The finding indicated that receiving an example from the teacher was the learning input that the introvert learners' need. This finding is obviously in line with the first learning needs. According to Gelbreg (2008), introvert learner's process information more slowly and longer. After catching up in the long pathways of their thoughts, they do not realize that they have not communicated them out load. Therefore, receiving an example from their teacher will help them to follow and understand the learning material. They will have an opportunity to involve in oral activities and improve language use.

The last learning needs deals with introvert learners' learning style. When the learners know his/her learning style, they will utilize it in the learning process so they will learn more easily 
and successfully. According to Knoll, Otani, Skeel \& Van Horn (2017), learning style is defined as the individual's preference for how learning material is presented. Based on the findings, listening to English music or song was their usual learning style for introvert learners. Almutairi \& Shukri (2016) presented the reason why learners like to listen to songs. According to them, the learners love song because they enjoy singing. In addition, songs help the learners to imitate and remember the words.

\section{CONCLUSION AND SUGGESTION}

The study revealed that the learners' necessities in English speaking activity based on the quantitative and qualitative data are in order to communicate properly in English and facilitate their learning in other skills such as listening, writing, and reading. Moreover, the difficult learning material and the lack of vocabulary were considered as the main lacks for the introvert learners in English speaking activity. They have more complex problem related to learning material and vocabulary because fear of making a mistake and lack of selfconfidence dominate their feelings. These factors make the introvert learners rarely improve the language use opportunities, tend to be listeners, and are uncomfortable in social situations.

In order to overcome the introvert learners' problems in English speaking activity, the English teacher plays an important role in choosing the appropriate learning needs for the learners. Based on the fact that there are extrovert and introvert learners in one classroom, the English teacher can offer the activities which are corresponding for all learners in English speaking activity. In this regard, the introvert and extrovert learners like to discuss the interesting topics, watching an English movie or video, and listening English song. The finding showed that introvert learners' interesting topic focuses on the experience which is in line with their learning material. Experience can be an interesting topic because the introvert learners can explore and develop their ideas from real life experience or personal record. The introverts also considered pair work as the effective work dynamics since it provides each of learners a lot of speaking time, motivation and more confidence to complete the task than doing individually.

As the introvert learners usually fill more pause and tend to need several times to think before saying something, the teacher can give them keywords and examples in order to help them in 
participating a speaking activity. In addition, providing English songs in the learning process will help the introvert learners to imitate and remember a range of vocabulary. The songs promote not only their speaking skill but also listening skill, vocabulary and pronunciation. By identifying the necessities, lacks, wants, and learning needs, the teacher can decide what kind of activities, learning materials, techniques, and learning input are preferred and needed by the learners.

Moreover, several limitations of the present study need to be considered in the following research. Further researchers who are interested in carrying out the similar issues should evaluate the study and dig more detail information deals with introvert learner's necessities, lack, wants, and learning needs qualitatively. Likewise, the researcher in the present study only utilized one way in classifying the learners. The result of personality test could have been more valid and reliable if the researcher also conducts observation and do collaboration with psychological expert.

\section{REFERENCES}

Abali, F. (2006). The Effect of Personality Traits Extroversion/Introversion on Verbal and Interactive Behaviors Learners. Master Thesis, Bilkent University, Ankara.
Alharbi, H. A. (2015). Improving students' English speaking proficiency in Saudi public schools. International Journal of Instruction, 8(1):105-116.

Al-Hosni, S. (2014). Speaking difficulties encountered by young EFL learners. International Journal on Studies in English Language and Literature, 2(6): 22-30.

Almutairi, M., \& Shukri, N. (2016). Using songs in teaching oral skills to young learners: teachers' views and attitudes. International Journal of Linguistics, 8(6): 133-153.

Altunel, V. (2015). The Impact of Extroversion and Introversion on Language Learning in an Input-Based EFL Setting. Doctoral dissertation, University of Kansas.

Alqahtani, M. (2015). The importance of vocabulary in language learning and how to be taught. International journal of teaching and education, 3(3): 21-34.

Autila, R. (2017). Improving students' writing skill of recount text through diary writing. TELLUS Journal, 3(1): 45-54.

Bergil, A. S. (2016). The influence of willingness to communicate on overall speaking skills among EFL learners. Procedia-Social and Behavioral Sciences, 232: 177-187.

Cahyono, B. Y., \& Widiati, U. (2015). The teaching of EFL vocabulary in the Indonesian context: the state of the art. TEFLIN journal, 19(1): 1-17.

Davidson, B., Gillies, R. A., \& Pelletier, A. L. (2015). Introversion and medical student education: Challenges for both students and educators. Teaching and learning in medicine, 27(1): 99-104.

Davies, J. (2019). The dialogic approach: replacing monologue with dialogue. Education Today, 28-31. 
Dörnyei, Z. (2005). The psychology of the language learner: Individual differences in second language acquisition. New York: Routledge.

Elfiza, R. (2017). The effect of using adventure game and picture on introverted students' speaking skill. Proceeding of International Conference on Art, Language, and Culture. 2(1): 357-366.

Francis, L. J., Lewis, C. A., Ziebertz, H. G. (2006). The short-form revised Eysenck personality Questionnaire (EPQ-S): A German edition. Social Behavior and Personality, 34(2): 197204.

Gelbreg, W. (2008). The successful introvert: How to enhance your job search and advance your career. California: Happy About Press.

Grave, K. (2002) Designing language courses: A guide for teachers. Boston, MA: Heinle \& Heinle.

Hakim, M. A. R. (2018). A research and development study to EFL learners: Designing a speaking module for introvert students based on cooperative learning. International Journal of English and Education, 7(2): 1-17.

Hakim, M. A. R. (2017). Teachers' strategies in teaching speaking lessons on introvert students in Madrasah Aliyah (MA) JA ALHAQ Bengkulu. Madania: Jurnal Kajian Keislaman, 21(1): 23-30.

Hakim, M. A. R. (2015). Experienced EFL teachers' challenges and strategies in teaching speaking for introvert students. European Journal of Social Sciences, 48(4): 437-446.

Hiouani, H. (2016). Teacher's Roles in Enhancing Introverted EFL Learners' Oral Fluency. Doctoral Dissertation, Mohamed Kheider University, Biskra.
Ihsan, H. (2015). Validitas isi alat ukur penelitian konsep dan panduan penilaiannya. Pedagogia: Jurnal Ilmu Pendidikan, 13(2): 266-273.

Ihsan, M. D., \& Ardhityawan, D. (2016). The influence of students' writing skill by writing diary in recount text for junior high school students. AESTHETICS, 5(1): 1-4.

Isazadeh, P., Makui, S. M. Z., \& Ansarian, L. (2016). Effect of instructional vs. authentic video materials on introvert and extrovert Iranian EFL learners' vocabulary learning. International Journal of Education and Literacy Studies, 4(4): 1-10.

Jiménez, R. T., David, S., Fagan, K., Risko, V. J., Pacheco, M., Pray, L., \& Gonzales, M. (2015). Using translation to drive conceptual development for students becoming literate in English as an additional language. Research in the Teaching of English, 248-271.

Kayalar, F., \& Kayalar, F. (2017). The effects of auditory learning strategy on learning skills of language learners (students' views). IOSR Journal of Humanities And Social Science (IOSR-JHSS), 22(10): 4-10.

Kristo, S. (2012). The Relationship between Extroversion/Introversion,

Perceptual Learning Styles and Jua Success in English as a Foreign Language. Diploma Paper, J.J. Strosmayer. University, Osijek

Knoll, A. R., Otani, H., Skeel, R. L., \& Van Horn, K. R. (2017). Learning styles, judgements of learning, and learning of verbal and visual information. British Journal of Psychology, 108(3): 544563.

Li, M.P., \& Lam, B. H. (2013). Cooperative learning. The active classroom. The Hong Kong Institue of Education. 
Michelene T. H. Chi, Seokmin Kang \& David L. Yaghmourian. (2017). Why studentslearn more from dialoguethan monologue-videos: analyses of peer interactions, Journal of the Learning Sciences, 26(1): 10-50.

Mundhe, G. B. (2015). Teaching receptive and productive language skills with the help of techniques. Pune Research an International Journal in English, 1(2): 1-6.

Nilsson, O., \& Hay, P. (2016). Group Works Impact on the Cognitive Learning Processes in the ESL Classroom. Master Thesis, högskolepoäng.

Nunan, D. (2004). Task-based language teaching. Cambridge: Cambridge University Press.

Omar, B. (2015). The effectiveness of extroverted and introverted personality in ability to get a higher proficiency in second language learning. Journal of Second Language Acquisition. 1-16.

Page, A., \& Stoneburgh, M. (2019). A structure for successful conversation in the ESL classroom. Kanda Academic Review. 1 10.

Poedjiastutie, D., \& Oliver, R. (2017). Exploring students' learning needs: expectation and challenges. English Language Teaching, 10(10): 124.

Pratiwi, M. R. (2010). Improving Pronunciation Ability Using Cartoon Films: A Collaborative Action Research of the Eighth Grade Students of SMPN 1 Kaliwiro in 2009/2010. Doctoral dissertation, Universitas Sebelas Maret, Surakarta.

Qutob, M. M. (2018). The Relationship between EFL learners' satisfaction within theclassroom environment and their speaking skills. English Language Teaching, 11(7): 116.
Salam, S. (2017). Developing needs analysis based-reading comprehension learning materials: A study on the Indonesian language study program students. Advances in Language and Literary Studies, 8(4): 105-113.

Sari, A., \& Sugandi, B. (2015). Teaching English through English movie: Advantages and disadvantages. The Journal of English Literacy Education: The Teaching and Learning of English as a Foreign Language, 2(2): 10-15.

Swanson, E., Wanzek, J., McCulley, L., Stillman-Spisak, S., Vaughn, S., Simmons, D., Fogarty, M., \& Hairrell, A. (2016). Literacy and text reading in middle and high school social studies and English language arts classrooms. Reading E Writing Quarterly, 32(3): 199222.

Uzer, Y. (2018). The influence of students' personality types to their speaking achievement on the tenth grade students of the state senior high school 6 Palembang. ANGLO

SAXON: Jurnal Ilmiah Program Studi PendidikanBahasa Inggris, 8(2).

Wen, L. (2017). A Study on Teaching Strategies for Introvert Learners in Chinese Elementary School. Master Thesis, University of Wisconsin, Platteville.

Wu, S. Y., \& Hou, H. T. (2015). How cognitive styles affect the learning behaviors of online problem-solving based discussion activity: A lag sequential analysis. Journal of Educational Computing Research, 52(2): 277-298.

Yulmiastri, Atmowardoyo, H., \& Salija, K. (2019). The Learning Styles of Students and Their Problems in Speaking English at the Second Grade of MAN Pangkep. Doctoral Dissertation, State University of Makassar, Makassar 
Zack, D. (2010). Networking for people who hate networking: A field guide for introverts, the overwhelmed and the under connected. San Francisco:

Berrett-Koehler Publishers.

\section{Table 2. APPENDIX}

The followings are the examples of college students' academic writing essay

\begin{tabular}{|c|c|c|c|}
\hline No & Need Analysis & Criteria & Result \\
\hline \multirow[t]{2}{*}{1.} & Necessities & Goal & $\begin{array}{l}\text { The introvert learners learn } \\
\text { speaking skill in order to } \\
\text { communicate properly in English } \\
\text { and facilitate their learning in other } \\
\text { skills }\end{array}$ \\
\hline & & $\begin{array}{l}\text { The most important speaking } \\
\text { aspect }\end{array}$ & Vocabulary \\
\hline \multirow[t]{2}{*}{2.} & Lacks & Learners' problem & The learning material is too difficult \\
\hline & & $\begin{array}{l}\text { The most difficult speaking } \\
\text { aspect }\end{array}$ & Vocabulary \\
\hline \multirow[t]{5}{*}{3.} & Wants & $\begin{array}{l}\text { The favourite English-speaking } \\
\text { activity }\end{array}$ & Discussing the interesting topics \\
\hline & & $\begin{array}{l}\text { Learners' interest in a speaking } \\
\text { activity }\end{array}$ & Discussing the interesting topics \\
\hline & & $\begin{array}{l}\text { Learners' interest in } \\
\text { pronunciation activity }\end{array}$ & $\begin{array}{l}\text { Watching a video with the English } \\
\text { subtitle, writing the unknown } \\
\text { words and reciting them }\end{array}$ \\
\hline & & The interesting topic & Experience \\
\hline & & The favourite speaking material & Dialogue \\
\hline \multirow[t]{6}{*}{4.} & Learning Needs & Teacher's role & $\begin{array}{l}\text { Giving keyword when they } \\
\text { experience the difficulties }\end{array}$ \\
\hline & & Learners' Role & $\begin{array}{l}\text { Listening to their teacher' } \\
\text { explanation }\end{array}$ \\
\hline & & The effective work dynamics & Pairs \\
\hline & & The effective technique & Translation \\
\hline & & The learning input & $\begin{array}{l}\text { Receiving examples from the } \\
\text { teacher }\end{array}$ \\
\hline & & Learning style & Listening to English song \\
\hline
\end{tabular}

